\title{
NUMERICAL SIMULATION OF THE EXIT TEMPERATURE PATTERN OF AN AIRCRAFT ENGINE USING A TEMPERATURE- DEPENDENT TURBULENT SCHMIDT NUMBER
}

\author{
Igor F. Kravchenko (i) 0000-0003-2304-3356 \\ Dmytro V. Kozel ${ }^{*}$ (DD 0000-0002-7295-2284 \\ Serhii A. Yevsieiev (DD 0000-0001-5231-0826 \\ SE “Ivchenko-Progress”, 2, Ivanova str., 69068, Zaporozhye, Ukraine \\ *kozeldv@ivchenko-progress.com
}

\begin{abstract}
This paper presents a numerical simulation for predicting the combustor exit temperature pattern of an aircraft engine, developed using the commercial fluid simulation software Ansys Fluent, which assumes a shape probability density function for the instantaneous chemistry in the conserved scalar combustion model and the standard $\mathrm{k}-\varepsilon$ model for turbulence. We found the compliance of the radial and circumferential non-uniformities of the exit temperature with the experimental data to be insufficient. To achieve much more accurate result, the mixing intensity was enhanced with respect to the initial calculation due to using the reduced value of the turbulent Schmidt number Sc. Numerical simulation was performed for values of the turbulent Schmidt number from $S c=0.85$ (default) up to $S c=0.2$, with results confirming the reduction of radial and circumferential non-uniformities of exit temperature. However, correlation between radial and circumferential non-uniformities is not admissible for these cases. Therefore, we propose to use a temperature-dependent formulation of the turbulent Schmidt number Sc, accounting for the increase in Sc number with increasing gas temperature. A user defined function (UDF) was used to implement the Sc number temperature dependence in Ansys Fluent. The numerical results for the proposed Schmidt number Sc temperature dependence were found to be in acceptable agreement with the experimental data both for radial and circumferential non-uniformities of the exit temperature pattern.
\end{abstract}

Keywords: Combustion chamber, exit temperature pattern, turbulent Schmidt number, temperature dependence, numerical simulation, UDF, ANSYS Fluent.

Type of the work: Research Article

\section{INTRODUCTION}

The reliability and lifetime of the turbine in a gas turbine engine depends on the exit pattern factor. Therefore, it is very relevant and important for combustion chamber design to simulate correctly the radial and circumferential non-uniformities of the gas temperature pattern. Given the large number of physical processes that occur in the combustor and the complexity involved in mathematical modeling of these processes, it is difficult to calculate the exit temperature pattern correctly using empirical and analytical methods. Computational fluid dynamics (CFD) can be used for this task. 
However, the experience of combustion chamber calculations performed during design processes, as well as analysis of the work of other authors $[1,2]$, have shown that the standard $\mathrm{k}-\varepsilon$ turbulence model underpredicts the mixing intensity and makes it possible to obtain good agreement with experimental data only for the radial temperature distribution factor (RTDF). The overall temperature distribution factor (OTDF) is in poor agreement with experimental results for this case [1-3]. However, for the turbine of a gas turbine engine, it is very important to ensure trends for both the RTDF, which affects the resource of the turbine rotor, and for the OTDF, which affects the resource of the stator parts of the turbine.

The objective of this article, therefore, is to develop a methodological approach to ensure a good agreement for both RTDF and OTDF. The study considers the gas flow with the combustion of liquid atomized fuel in the combustor (sector 1/18) of a gas turbine engine (see Fig. 1). The design investigated in this work is the combustor of the D-436-148FM aero engine powering the double aisle aircraft Antonov 178, an engine developed by SE Ivchenko-Progress, Ukraine. The main parameters and characteristics of this combustion chamber for the takeoff mode are presented in Table 1.

Table 1. Parameters and characteristics of combustion chamber for takeoff mode.

\begin{tabular}{|c|c|c|}
\hline Parameter & Dimension & Value \\
\hline Air mass flow rate in the combustion chamber, $\mathrm{W}_{3}$ & $\mathrm{~kg} / \mathrm{s}$ & 36.46 \\
\hline Total inlet pressure, $\mathrm{P}_{3}$ & $\mathrm{kPa}$ & 2353.6 \\
\hline Stagnation temperature ahead of combustion chamber, $\mathrm{T}_{3}$ & $\mathrm{~K}$ & 771 \\
\hline Inlet Mach number, $\mathrm{M}_{3}$ & - & 0.3 \\
\hline Excess air coefficient, $\alpha$ & - & 3.13 \\
\hline Total pressure losses for flame tube, $\delta$ & $\%$ & 3.9 \\
\hline Fuel combustion efficiency, $\eta$ & $\%$ & 99.8 \\
\hline Radial temperature distribution factor at the exit plane, RTDF & $\%$ & $<12$ \\
\hline Overall temperature distribution factor at the exit plane, OTDF & $\%$ & $<30$ \\
\hline
\end{tabular}

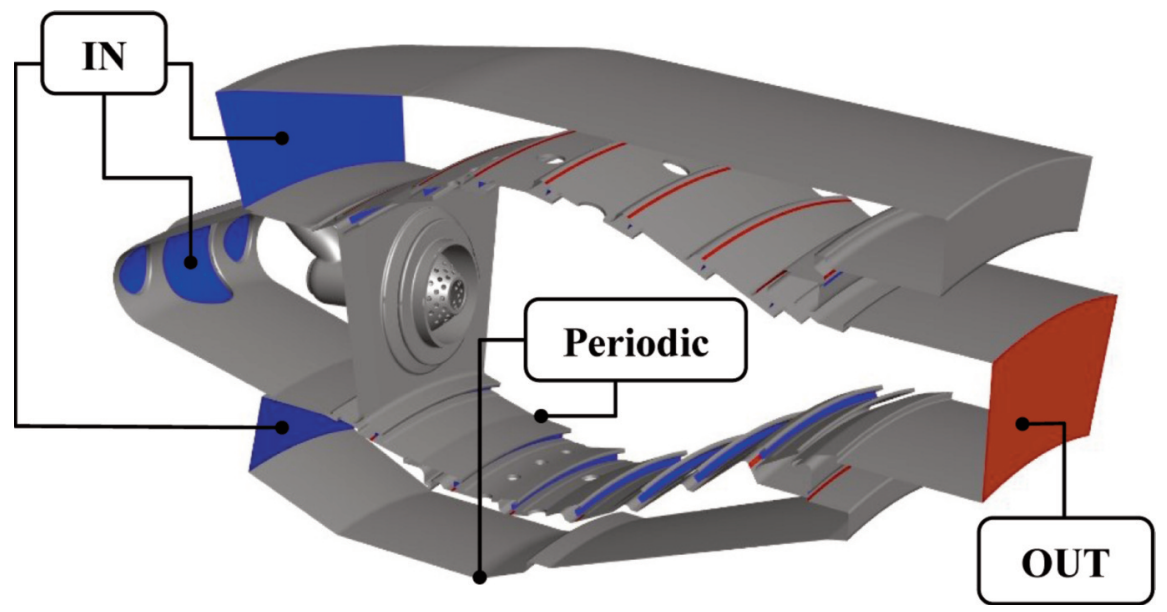

Fig. 1. The geometry of combustor for simulation. 
In this study, the physical model of a viscous gas and its mathematical model as a system of Reynoldsaveraged Navier-Stokes equations (RANS), including the equation of conservation of mass (equation of continuity), the equation of conservation of momentum and energy, were used for the CFD method. To close the system of Reynolds averaged equations, standard k- $\varepsilon$ turbulence models and combustion model with presumed probability density function were used [4-7]. The finite differences method was used for discretization of partial differential equations. The choice of this method is justified by the fact that it allows good agreement to be obtained for numerical results and the computational time to be reduced [8].

Since the choice of applied turbulence model parameters is very impotent for simulation, we studied the influence of turbulence model parameters on the results of simulation. The degree of turbulent diffusion plays one of the main roles in the mixing of burnt and fresh parts of mixture and in the formation of the temperature pattern. In [1] turbulent Schmidt numbers of 1.0 and 0.5 were used. For the purposes of this study, we decided to investigate the influence of turbulent Schmidt number Sc on RTDF and OTDF in more detail.

We studied the influence of the turbulent Schmidt number Sc on the agreement of numerical results with experimental data for full annular rig test results. As a result, to ensure good agreement with experimental data both for RTDF and for OTDF, we proposed to use a temperature-dependent formulation of the turbulent Schmidt number Sc, instead of a constant value.

\section{EXPERIMENT}

A full-sized combustion chamber D-436-148FM was used for the experiment, performed at the test rig of SE Ivchenko-Progress. The photo in Fig. 2 shows the combustion chamber installed at the test rig. The total pressure losses for the flame tube, radial and circumferential temperature pattern factor at the exit of combustion chamber were measured. The rig was equipped with total pressure rakes, static pressure tappings and thermocouples for monitoring the inlet parameters. To obtain the temperature exit profile of the combustor, 12 lines of the rake were analyzed. The exit temperature rake was traversed in the circumferential direction measuring at 600 angular positions.

The mode parameters for the test rig are presented in Table 2. A quasi-non-dimensional Mach number was determined from the engine compressor exit conditions (see Table 1). The scaling strategy resulted in an air mass flow $\mathrm{W}_{3}$ of $8.93 \mathrm{~kg} / \mathrm{s}$ in the rig when the pressure in the test rig was set as fixed parameters $\mathrm{P}_{3}=549.17 \mathrm{kPa}$. The tests were therefore carried out with no scaling of the temperature at the inlet and outlet of the combustion chamber, as well as the Mach number $\mathrm{M}_{3}$ (corresponding to the takeoff regime of the engine, see Table 1 and 2). At the same time, the inlet pressure and air mass flow rate are fixed $549.17 \mathrm{kPa}$ and about $8.93 \mathrm{~kg} / \mathrm{s}$, respectively. These thermodynamic combustion chamber inlet boundary conditions for the full annular rig test represent reduced takeoff conditions. It is assumed, that scaling strategy for rig provides the correspondence of the exit temperature pattern to a full takeoff conditions.

Table 2. Mode parameters for the test rig (reduced takeoff conditions).

\begin{tabular}{|c|c|c|}
\hline Parameter & Dimension & Value \\
\hline Air mass flow rate in the combustion chamber, $\mathrm{W}_{3}$ & $\mathrm{~kg} / \mathrm{s}$ & 8.93 \\
\hline Total inlet pressure, $\mathrm{P}_{3}$ & $\mathrm{kPa}$ & 549.17 \\
\hline Stagnation temperature ahead of combustion chamber, $\mathrm{T}_{3}$ & $\mathrm{~K}$ & 770 \\
\hline Excess air coefficient, $\alpha$ & - & 3.10 \\
\hline Inlet Mach number, $\mathrm{M}_{3}$ & - & 0.30 \\
\hline
\end{tabular}




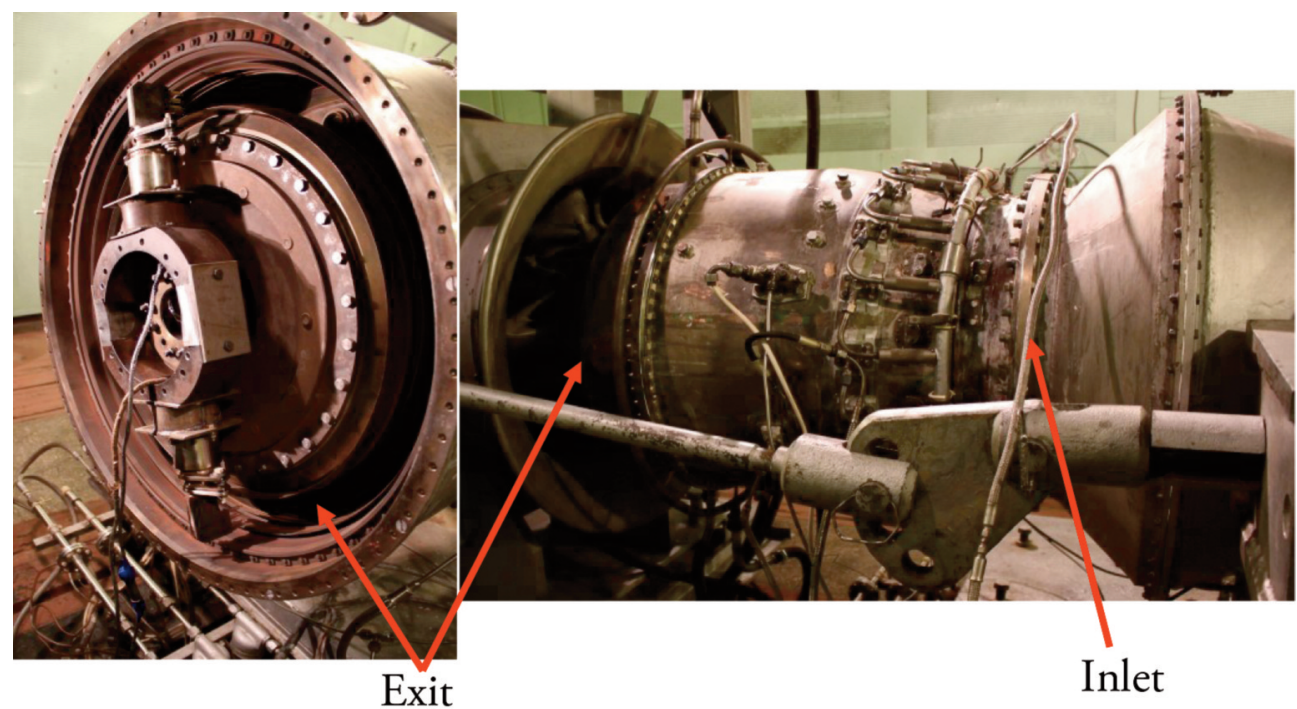

Fig. 2. The combustion chamber installed at the test rig of SE Ivchenko-Progress.

\section{METHOD FOR NUMERICAL SIMULATION AND BOUNDARY CONDITIONS}

\subsection{Physics and mathematical model of the problem}

The ANSYS Fluent software was used to simulate the gas flow and combustion process of kerosene fuel. ANSYS Fluent implements a numerical solution of the Reynolds averaged Navier-Stokes equations, including the mass conservation, momentum conservation, and energy equations. The Realizable k- $\varepsilon$ turbulence model of Launder-Spalding was used to close the system of Reynolds averaged equations. Discretization of partial differential equations is carried out using finite volume methods.

For modeling of combustion, the model of the unmixed mixture was used [9]. An assumed shape probability density function (pdf) was used for the instantaneous chemistry in the conserved scalar combustion model - equilibrium pdf combustion model using 16-species chemistry. The Discrete Phase Model was used for modeling the movement, heat transfer and evaporation of droplets of atomized liquid fuel [10-12]. The following basic assumptions were also made:

- viscous heating and radiation heat transfer are neglected;

- the gas flow is incompressible;

- the volume occupied by the fuel droplets and the influence of the fuel droplets on the turbulence characteristics are neglected;

- the gas model is a multicomponent chemically reacting mixture of thermodynamically perfect gases that are part of the fuel, oxidizer and combustion products.

\subsection{Computational mesh}

A rational choice of computational mesh should represent a reasonable compromise between computational costs, agreement of the numerical results, and the cost of mesh construction. That is why the construction of the computational mesh relates to the key points of the CFD method.

A hexahedral mesh of a special type (the so-called "cartographic") with the shape and location of cells along of the flow and the gradients of independent variables can provide the highest accuracy of calculation. In practice, these conditions can only be partially satisfied, since the structure of the flow is not known beforehand. 
Moreover, the computational domain has a complex form and the construction of cartographic mesh using modern mesh generators is often impossible. Therefore, to generate a cartographic mesh the computational domain can be divided into elementary subdomains with much lower geometric complexity. For geometrically complex domains, it is easier to use a tetrahedral computational mesh. However, due to the fundamental inconsistency with the flow direction, a tetrahedral mesh provides lower accuracy. Also, with the same resolution, the tetrahedral mesh has significantly more elements than the hexahedral mesh.

The computational domain for the combustor, including the single-burner sector, is geometrically complex, multiconnected and multi-scaled. A compromise solution is to use a combined (hybrid) mesh, which consists of hexahedra, tetrahedra, connecting pyramids, as well as prisms. A hybrid mesh provides significant savings for the total number of cells and increases the accuracy of the calculation compared to purely tetrahedral ones. to build a hyrid mesh, the computational domain of the combustor must be decomposed into subdomains (blocks). In most blocks inside the liner and in the annular channels, a hexahedral mesh should be used. The most complex blocks of the computational domain, where the construction of hexahedral and prismatic mesh causes difficulties, should be covered with a tetrahedral mesh.

We constructed a mesh for exit temperature pattern calculation in accordance with the above principles. The computational mesh contained -36 million cells (see Fig. 3), taking into account the adaptation results in the area of mixing holes. It should be noted that the value $y+\sim 30$ is also most desirable because it corresponds to the lower limit of the completely turbulent zone of the boundary layer [13].

\subsection{Boundary conditions}

Fig. 1 shows a scheme for the boundary conditions. For the inlet boundary (IN) the mass flow rate, the total temperature, the turbulence intensity, and the ratio of turbulent viscosity to dynamic viscosity were set. The total temperature of the return flow and the pressure were set for outlet boundary (OUT). The type of Rotational-periodic boundary conditions was set on the lateral faces of computational domain.

The boundary conditions on the solid wall for finding shear stresses, turbulence kinetic energy (TKE) and dissipation rate of TKE were determined using the wall function (Standard Wall Functions) [14].

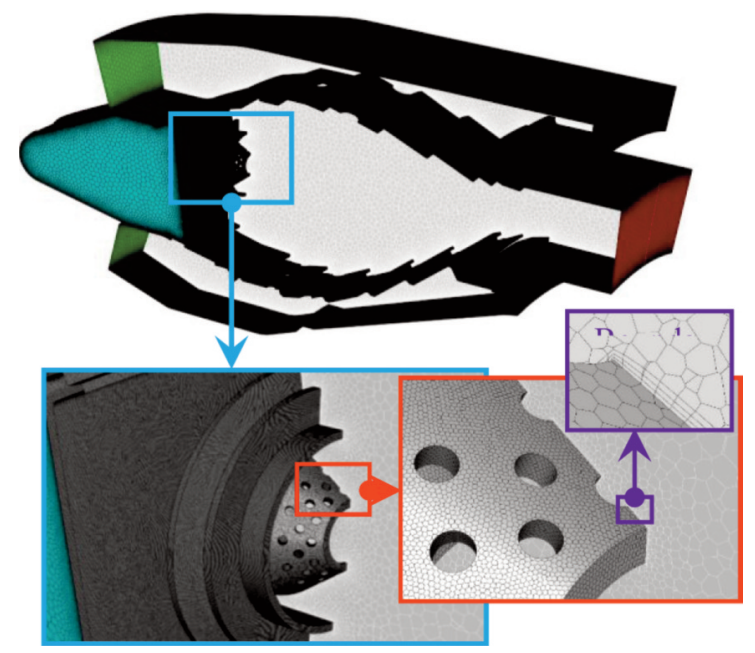

Fig. 3. Computational mesh. 


\subsection{Numerical simulation method}

Parameters and characteristics for numerical method are shown in Table 3.

Table 3. Numerical solution parameters and characteristics.

\begin{tabular}{|l|l|}
\hline Aspect of the numerical procedure & Fluent Program Option \\
\hline Solver & Segregated \\
\hline Gradient Option & Node-Based \\
\hline Pressure-Velocity Coupling & SIMPLE \\
\hline & Flow (4 equations) \\
& Turbulence (2 equations) \\
& Energy (1 equations) \\
& Probability density function for combustion model \\
& $(2$ equations) \\
& Total: (9 equations) \\
\hline Discretization scheme & First Order Upwind or Third Order MUSCL \\
\hline & Pressure - 0.2; \\
& Momentum - 0.5; \\
& Energy - 0.9; \\
& Temperature - 0.9; \\
& Mean Mixture Fraction $-0.9 ;$ \\
& Mixture Fraction Variance $-0.8 ;$ \\
& Discrete Phase Sources $-0.2 ;$ \\
& Rest by default. \\
\hline
\end{tabular}

\subsection{Mode parameters of the combustion chamber for simulation}

The mode parameters of the combustion chamber for the simulation, presented in Table 4, corresponded to the takeoff mode of the engine.

Table 4. Mode parameters of the combustion chamber for simulation.

\begin{tabular}{|c|c|c|c|}
\hline Parameter & Dimension & $\begin{array}{c}\text { Value (for full- } \\
\text { size combustion } \\
\text { chamber) }\end{array}$ & $\begin{array}{c}\text { Value (for } \\
\text { sector 1/18) }\end{array}$ \\
\hline Air mass flow rate in the combustion chamber, $\mathrm{W}_{3}$ & $\mathrm{~kg} / \mathrm{s}$ & 36.46 & 2.03 \\
\hline Total inlet pressure, $\mathrm{P}_{3}$ & $\mathrm{kPa}$ & 2353.6 & 2353.6 \\
\hline $\begin{array}{c}\text { Stagnation temperature ahead of combustion } \\
\text { chamber, } \mathrm{T}_{3}\end{array}$ & $\mathrm{~K}$ & 771 & 771 \\
\hline Excess air coefficient, $\alpha$ & - & 3.13 & 3.13 \\
\hline
\end{tabular}




\section{RESULTS}

We performed a numerical simulation of the gas flow with the combustion of atomized liquid fuel in the annular combustion chamber of an aircraft gas turbine engine. To validate the calculation model used, the numerical results were compared with the results of an experiment. The total pressure losses for flame tube, radial and circumferential non-uniformities of the exit temperature pattern were measured for this test.

The calculated linear total pressure losses for all cases were $4.1-4.2 \%$, while the measured value was $3.9 \%$, indicating satisfactory agreement of total pressure loss simulation. However, we found the agreement of the radial and circumferential non-uniformities of exit temperature to be unsatisfactory when using the standard k- $\varepsilon$ turbulence model with the default settings for Ansys Fluent (with a constant value for the turbulent Schmidt number, $\mathrm{Sc}=0.85$ ). The difference between experimental data and simulation results for the radial non-uniformity of the temperature pattern for this case is $14.6 \%$, and for the maximum value of the circumferential non-uniformity is $16.4 \%$ (see Fig. 5 and Table 6).

In the next stage of research, the turbulent diffusion intensity was increased with respect to the initial case by reducing the Sc value, expecting to reduce the non-uniformity of the exit temperature pattern. Simulations were performed for turbulent Schmidt numbers Sc $=0.6$; Sc $=0.4$ and Sc $=0.2$ [15-17].

The influence of the turbulent Schmidt number Sc on the calculation results is shown to be predictable (see Fig. 4 and 5): the circumferential and radial non-uniformities of the exit temperature pattern decrease with a decreasing Sc value. There is a good agreement with experimental data for radial non-uniformity (see Fig. 5) for the $S_{c}=0.2$ case, but the level of circumferential non-uniformity is very low for this case. An analysis of the obtained results showed that an increase in turbulent diffusion intensity leads to a stronger reduction in the circumferential non-uniformity of the temperature pattern than for the radial one. The circumferential non-uniformity of the exit temperature pattern forms due to the migration of hot streaks from the primary zone to the secondary zone of the combustor. The intensification of the mixing process due to large-scale turbulence during the injection of transverse jets of dilution air takes place only in dilution zone of combustor. Therefore, a more accurate simulation of exit temperature pattern must take into account the increase in the turbulent diffusion intensity only for the dilution zone of the combustor, where the gas temperature level is lower than in the primary and secondary zones.

Therefore, in the final stage of our research, seeking to achieve good agreement of calculation results for both circumferential and radial non-uniformities of the exit temperature pattern, we proposed to use a temperature-dependent formulation of the turbulent Schmidt number Sc, instead of a constant value. This function takes into account the increase in Sc number with increasing gas temperature. The User Defined Functions (UDF) [18] tool in Ansys Fluent was used to provide the turbulent Schmidt number Sc temperature dependence. Namely, a linear dependence of the type $S c=A \cdot T+B$ with limits $S_{c_{\min }}=0.2$ and $\mathrm{Sc}_{\max }=0.8$ was used, where: $\mathrm{T}-$ the temperature of gas; $\mathrm{A}$ and $\mathrm{B}$ - coefficients. Relative results for the radial and circumferential non-uniformities with using the default $S c h m i d t$ number $(S c=0.85)$ and the proposed UDF function are shown in Table 5.

Figure 6 shows the results of exit temperature pattern modeling using the Sc number temperature dependence thus formulated. There is a satisfactory agreement with the experimental data for both radial and circumferential non-uniformities of the exit temperature pattern. The calculated OTDF $=21.0 \%$ for this case is not much lower than the experimental OTDF $=27.3 \%$ because of the "idealized" computational model (without any size tolerance and fuel feed non-uniformity).

Thus, the obtained results confirm that correct modeling of the exit temperature pattern must take into account the fact that the turbulent diffusion intensity in the dilution zone of combustor is higher than in the primary and secondary zones, due to large-scale turbulence during the injection of transverse jets of dilution air. 

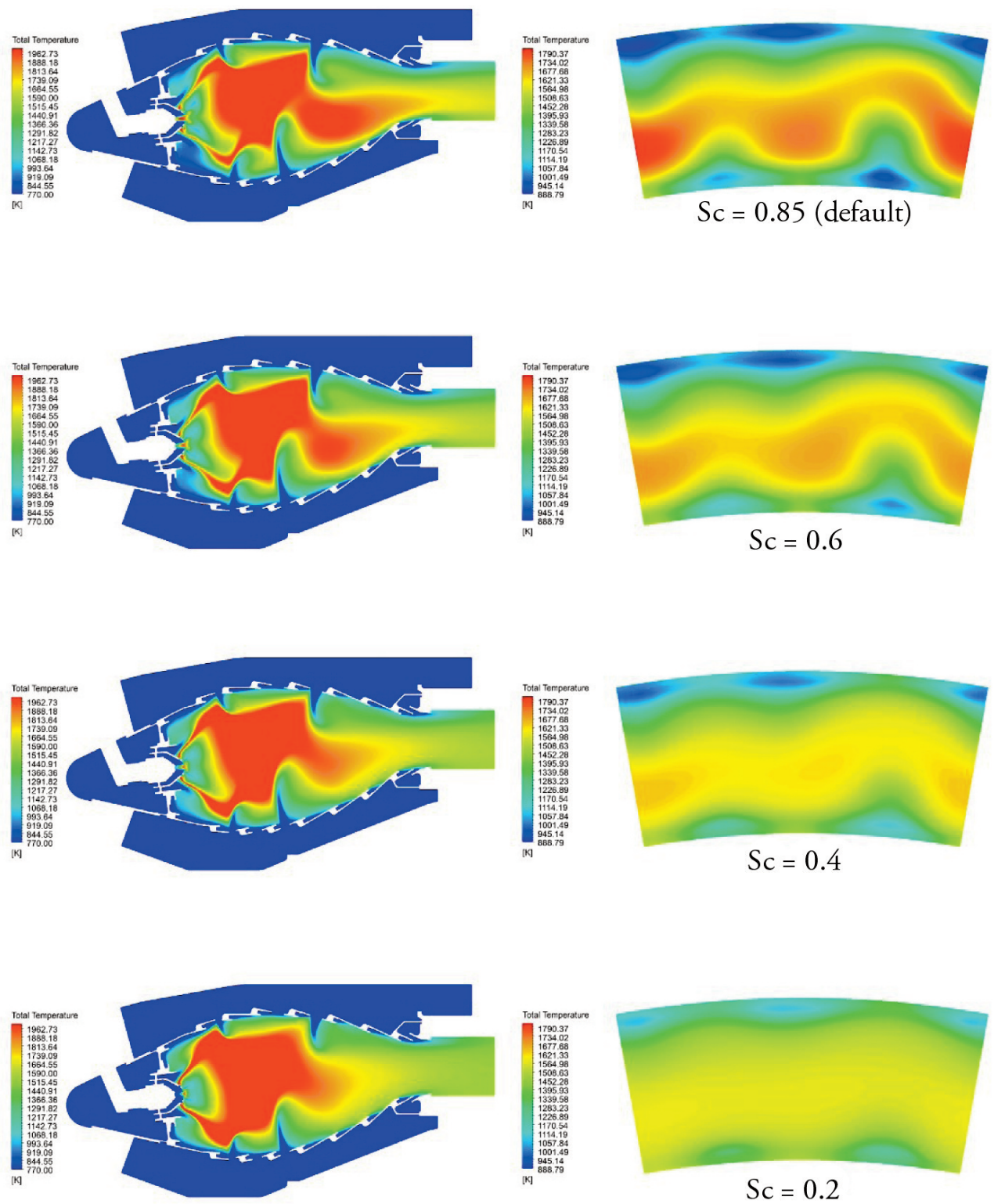

Fig. 4. The temperature pattern in the meridian and exit sections of the combustor for various values of turbulent Schmidt number $\mathrm{Sc}=0.85$ (default); 0.6; 0.4 and 0.2. 

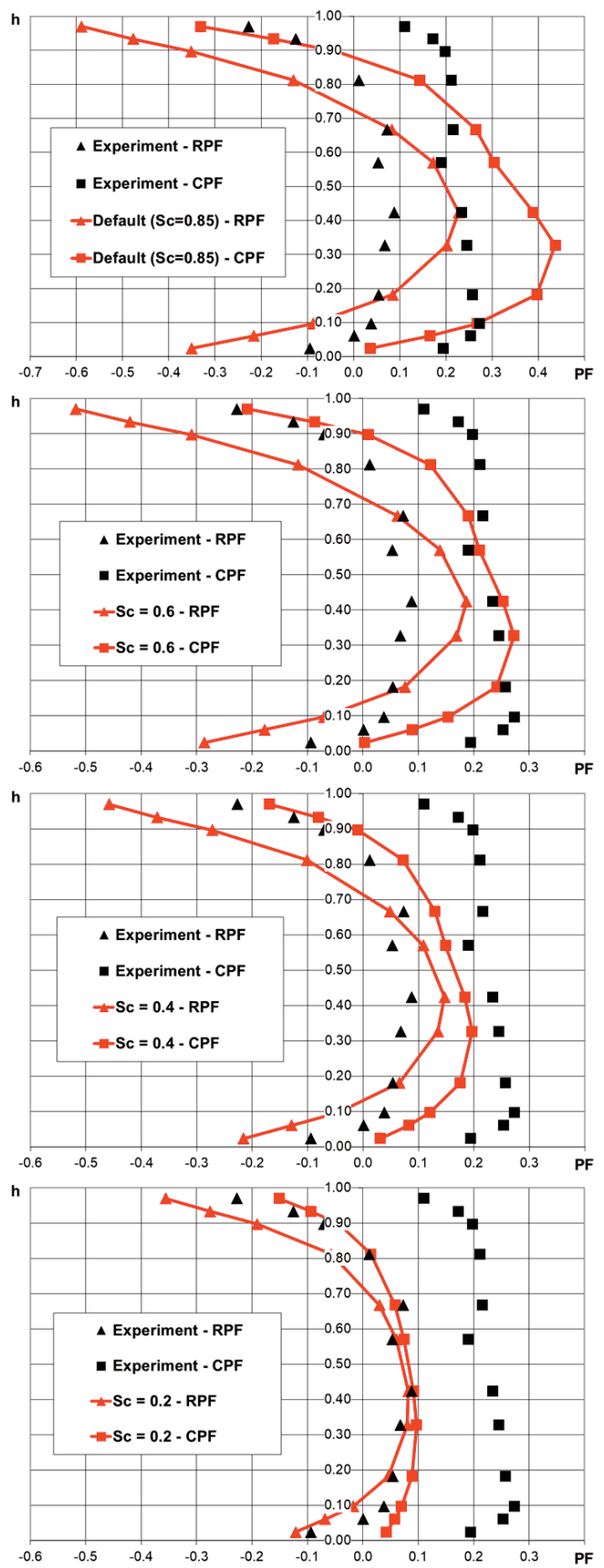

PF - Pattern Factor;

RPF - Radial Pattern Factor;

CFP - Circumferential Pattern Factor.

Fig. 5. Plots of the temperature pattern factor at the exit of the combustor for various values of turbulent Schmidt number Sc $=0.85$ (default), $0.6,0.4$ and 0.2 and experimental results. 

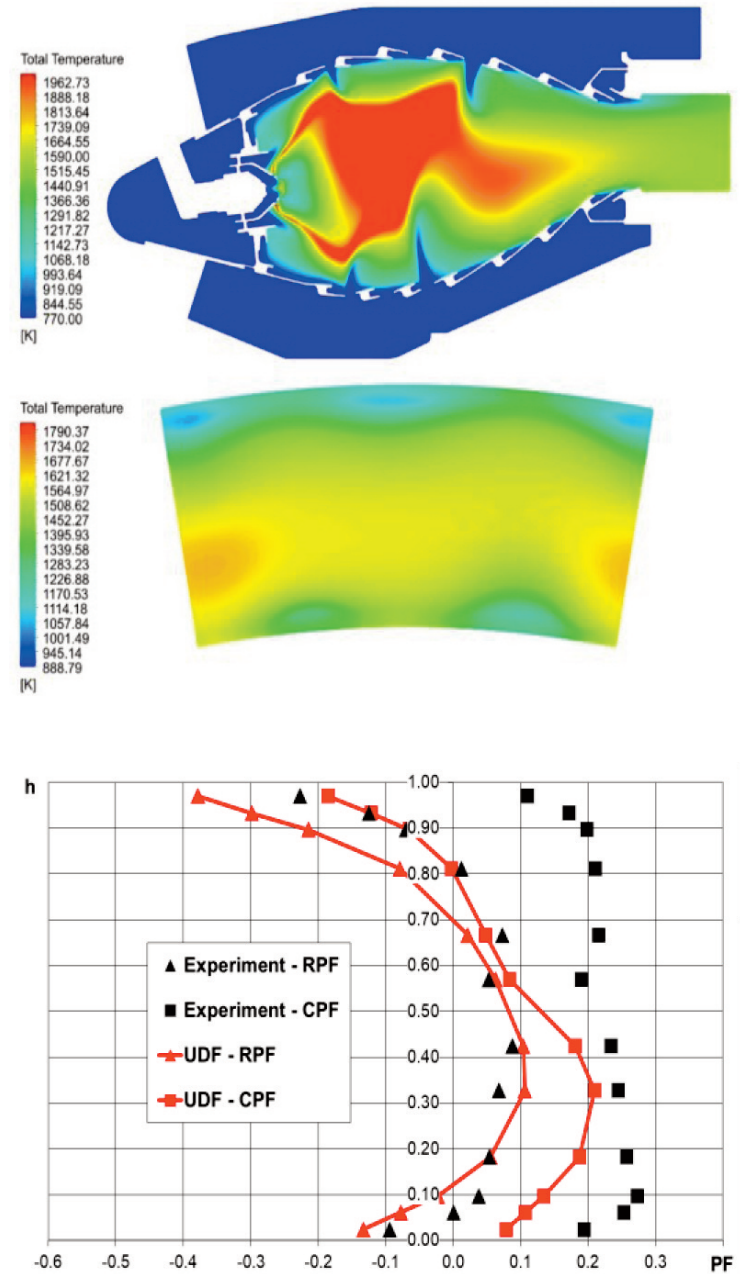

CFD simulation with UDF and experimental results;

PF - Pattern Factor;

CPF - Circumferential Pattern Factor.

Fig. 6. Experimental results for the gas temperature pattern and results of simulation with UDF. 
Table 5. The agreement of simulation results for radial and circumferential exit gas temperature non-uniformities.

\begin{tabular}{|c|c|c|c|c|}
\hline & \multicolumn{2}{|c|}{$\begin{array}{l}\text { Radial Temperature } \\
\text { Distribution Factor } \\
\text { (RTDF), \% }\end{array}$} & \multicolumn{2}{|c|}{$\begin{array}{l}\text { Overall Temperature } \\
\text { Distribution Factor } \\
\text { (OTDF), \% }\end{array}$} \\
\hline & $U D F$ & Default & $U D F$ & Default \\
\hline Simulation & 10.4 & 23.4 & 21.0 & 43.7 \\
\hline Experiment & \multicolumn{2}{|c|}{8.8} & \multicolumn{2}{|c|}{27.3} \\
\hline Agreement, \% & 1.6 & 14.6 & -6.3 & 16.4 \\
\hline
\end{tabular}

\section{CONCLUSIONS}

The following conclusions can be posited based on the results of numerical simulations:

1. Our investigation of the influence of turbulent Schmidt number Sc on the radial temperature distribution factor (RTDF) and overall temperature distribution factor (OTDF) confirmed that a lower value of the turbulent Schmidt number leads to a lower level of the circumferential and radial non-uniformities of the exit gas temperature pattern, due to the increased turbulent diffusion intensity of gas components in this case.

2. We found no satisfactory agreement with the experimental data for either the radial or circumferential non-uniformities of the exit temperature pattern for the case when a constant Sc value is used. This result can be explained by the fact that the intensification of the mixing process, due to largescale turbulence during the injection of transverse jets of dilution air, takes place only in the dilution zone of the combustor and it is necessary to take into account the increase in turbulent diffusion intensity only for the dilution zone of the combustor (not for all computation domains), where the gas temperature level is lower than in the primary and secondary zones.

3. To achieve good agreement of calculation results for both circumferential and radial non-uniformities of the gas exit temperature pattern, we propose to use a temperature-dependent turbulent Schmidt number Sc, instead of a constant value, accounting for the increase in Sc number with increasing gas temperature. The User Defined Functions (UDF) tool in Ansys Fluent can be used to provide functional dependence of the turbulent Schmidt number Sc on the gas temperature.

\section{REFERENCES}

[1] Barhaghi, D.G., and Hedlund, L., 2018, "Numerical investigation of fluid flow parameters in a combustor simulator," Proceedings of the ASME Turbo Expo 2018: Turbomachinery Technical Conference and Exposition. Volume 5C: Heat Transfer. Oslo, Norway. June 11-15, 2018. V05CT17A001. ASME. doi: 10.1115/GT2018-75018.

[2] Cubeda, S., Mazzei, L., Bacci, T., and Andreini, A. 2018. "Impact of Predicted Combustor Outlet Conditions on the Aerothermal Performance of Film-Cooled HPT Vanes." Proceedings of the ASME Turbo Expo 2018: Turbomachinery Technical Conference and Exposition. Volume 5C: Heat Transfer. Oslo, Norway. June 11-15, 2018. V05CT17A005. ASME.

[3] Smiljanovski, V., and Brehm, N. 1999. "CFD Liquid Spray Combustion Analysis of a Single Annular Gas Turbine Combustor." Proceedings of the ASME 1999 International Gas Turbine and Aeroengine Congress and Exhibition. Volume 2: Coal, Biomass and Alternative Fuels; Combustion and Fuels; Oil and Gas Applications; Cycle Innovations. Indianapolis, Indiana, USA. June 7-10, 1999. V002T02A055. ASME. doi: 10.1115/99-GT-300. 
[4] King, P.T., Andrews, G.E., Pourkashanian, M.M., and McIntosh, A.C., 2012, "CFD Predictions of Isothermal Fuel-Air Mixing in a Radial Swirl Low NOx Combustor Using Various RANS Turbulence Models." Proceedings of the ASME Turbo Expo 2012: Turbine Technical Conference and Exposition. Volume 2: Combustion, Fuels and Emissions, Parts A and B. Copenhagen, Denmark. June 11-15, 2012. pp. 973-983. ASME. doi: 10.1115/GT2012-69299.

[5] Launder, B.E. and Spalding, D.B., 1972, Lectures in Mathematical Models of Turbulence, Academic Press, London, England.

[6] Yakhot, V., and Orszag, S.A., 1986, "Renormalization Group Analysis of Turbulence: I. Basic Theory," Journal of Scientific Computing, 1(1), pp. 1-51.

[7] Shih, T.H., Liou, W.W., Shabbir, A., Yang Zh. and Zhu, J., 1995, A New k-ع Eddy-Viscosity Model for High Reynolds Number Turbulent Flows - Model Development and Validation, Computers \& Fluids, 24(3), pp. 227-238.

[8] Konle, M., de Guillebon, L., and Beebe, C., 2018, "Multi-Physics Simulations With OpenFOAM in the Re-Design of a Commercial Combustor." Proceedings of the ASME Turbo Expo 2018: Turbomachinery Technical Conference and Exposition. Volume 5C: Heat Transfer. Oslo, Norway. June 11-15, 2018. V05CT17A007. ASME. doi: 10.1115/GT2018.

[9] King, P.T., Andrews, G.E., Pourkashanian, M.M., and McIntosh, A.C., 2012, "Nitric Oxide Predictions for Low NOx Radial Swirlers With Central Fuel Injection Using CFD.” Proceedings of the ASME Turbo Expo 2012: Turbine Technical Conference and Exposition. Volume 2: Combustion, Fuels and Emissions, Parts A and B. Copenhagen, Denmark. June 11-15, 2012. pp. 985-993. ASME.

[10] Tong, A.Y., and Sirignano, W.A., 1986, "Multicomponent Droplet Vaporization in a High Temperature Gas," Combustion \& Flame, 66(3), pp. 221-235.

[11] Renksizbulut, M., Bussmann, M., and Li, X., 1992, "A Droplet Vaporization Model for Spray Calculations.” Particle \& Particle Systems Characterization, 9, pp. 59-65.

[12] Miller, R. S., Harstad, K., and Bellan, J. 1998, "Evaluation of Equilibrium and Non-Equilibrium Evaporation Models for Many-Drop-let Gas-Liquid Flow Simulations," International Journal of Multiphase Flow, 24(6), pp. 1025-1055.

[13] Averin S.I., Minaev A.N., Shvydkii V.S., and Yaroshenko Yu.G., 1987, Fluid and Gas Mechanics. Moscow, Metallurgy Publ.

[14] Launder, B.E., and Spalding, D.B., 1974, "The Numerical Computation of Turbulent Flows," Computer Methods in Applied Mechanics and Engineering, 3, pp. 269-289.

[15] King, P.T., Andrews, G.E., Pourkashanian, M.M., and McIntosh, A.C., 2012, "CFD Predictions of Isothermal Fuel-Air Mixing in a Radial Swirl Low NOx Combustor Using Various RANS Turbulence Models." Proceedings of the ASME Turbo Expo 2012: Turbine Technical Conference and Exposition. Volume 2: Combustion, Fuels and Emissions, Parts A and B. Copenhagen, Denmark. June 11-15, 2012. pp. 973-983. ASME. doi: 10.1115/GT2012-69299.

[16] Deissler, R.G., 1955, Analysis of turbulent heat transfer, mass transfer and friction in smooth tubes at high Prandtl and Schmidt numbers. Nat'1. Advis. Comm. Aero. Report 1210.

[17] Deissler, R.G., 1954, Analysis of turbulent heat transfer, mass transfer and friction in smooth tubes at high Prandtl and Schmidt numbers. Nat'1. Advis. Comm. Aero. Tech. Note 3145.

[18] ANSYS Fluent User's Guide, 2019, ANSYS Inc. 


\title{
NUMERYCZNA SYMULACJA ROZKŁADU TEMPERATURY WYLOTOWEJ SILNIKA Z WYKORZYSTANIEM LICZBY SCHMIDTA ZALEŻNEJ OD TEMPERATURY
}

\begin{abstract}
Abstrakt
W niniejszym artykule przedstawiono symulację numeryczną do przewidywania rozkładu temperatury przy wylocie z komory spalania silnika lotniczego, opracowaną przy użyciu komercyjnego oprogramowania Ansys Fluent. Przyjęto funkcję gęstości prawdopodobieństwa kształtu dla natychmiastowych reakcji chemicznych w zachowanym skalarnym modelu spalania oraz standardowy model k- $\varepsilon$ dla turbulencji. Stwierdzono niewystarczającą zgodność niejednorodności promieniowych i obwodowych temperatury wylotowej z danymi eksperymentalnymi. W celu uzyskania bardziej dokładnego wyniku, intensywność mieszania została wzmocniona w stosunku do początkowych obliczeń w związku z zastosowaniem zredukowanej wartości turbulentnej liczby Schmidta Sc. Symulacje numeryczne zostały przeprowadzone dla wartości turbulentnej liczby Schmidta od $S_{c}=0,85$ (domyślnej) do $S_{c}=0,2$, z wynikami potwierdzającymi redukcję niejednorodności promieniowej i obwodowej temperatury wylotowej. Jednakże korelacja pomiędzy niejednorodnością promieniową i obwodową nie jest dopuszczalna dla tych przypadków. Zaproponowano więc, żeby liczb turbulencji Schmidta Sc była ujęta w sposób uzależniony od temperatury, z rosnącym liczby Sc wraz ze wzrostem temperatury gazu. Posłużono się funkcją zdefiniowaną przez użytkownika (UDF) w oprogramowaniu Ansys Fluent w celu implementacji zależności liczby Sc od temperatury. Wyniki numeryczne otrzymane dla zaproponowanej zależności liczby Schmidta od temperatury były w akceptowalnej zgodzie z danymi eksperymentalnymi zarówno dla niejednorodności promieniowej, jak i obwodowej temperatury wylotowej.
\end{abstract}

Słowa kluczowe: komora spalania, wzór temperatury wylotowej, turbulentna liczba Schmidta, zależność od temperatury, symulacja numeryczna, funkcja zdefiniowana przez użytkownika, ANSYS Fluent 